\title{
Research on China's Management Mechanism of Green Product Standardization - Based on Comparison of Chinese and Foreign Green Product Standards
}

\author{
Yi Zhu*, Yun Fu, Ling Lin, Dongfeng Gao, Yanxin Gao and Wanying Zhao
}

(China National Institute of Standardization, Beijing, 100191)

\begin{abstract}
Green products are medium and high-end products that conform to the construction of ecological civilization, and it is extremely necessary to promote the standardization of green products. Therefore, this paper makes a comparative study of Chinese and foreign green product assessment standards, studies the coordination and management mechanism of green product standard development and green product certification of China, analyzes the progress and problems of China's green product assessment standardization, and thus puts forward relevant suggestions.
\end{abstract}

\section{Introduction}

The report of the 19th CPC National Congress of China clearly proposes to speed up the establishment of a legal system and policy guidance for green production and consumption, establish and improve a green and lowcarbon circular economic system, and build a marketoriented green technological innovation system. The Overall Plan for the Reform of the Ecological Civilization System issued by the CPC Central Committee and the State Council proposes to establish a unified green product system to integrate the environmental friendly, energy-saving, water-saving, recycled, low-carbon, renewable, organic and other products currently established separately into green products, as well as to establish a unified system of green product standards, certification, and labelling. In November 2016, the General Office of the State Council issued the Opinions on Establishing a Unified System of Standards, Certification and Labelling of Green Products, proposing that improving the green market system and increasing the supply of green products are important components of the reform of the ecological civilization system. In addition, establishing a unified system of green product standards, certification and labelling is an inevitable requirement to promote the development of green and low-carbon circulation and cultivate a green market; an important measure to strengthen the structural reform on the supply side and improve the quality and efficiency of the supply of green products; an urgent task to guide industrial transformation and enhance China's manufacturing competitiveness; an effective way to lead green consumption, ensure and improve people's livelihood; and also a realistic need for fulfilling international emission reduction commitments and enhancing China's institutional voice in global governance.
Research institutions, government departments and scholars at home and abroad have carried out a series of researches on green products from different dimensions. As for foreign studies, in order to enable consumers to identify green products recognized by the government, Germany introduced the eco-label system for the first time in the world in 1979, and now about 40 countries and regions such as the European Union, Northern Europe, Canada, the United States and Japan are implementing the system. Research institutions and scholars in Britain, the United States, Denmark, the European Union and other countries and regions have done a lot of research on life cycle assessment (LCA) and method improvement, input-output method, cost analysis method and other green product assessment related methods. The domestic studies mainly include ecological (green) design product research, research on green product certification implementation, and research on foreign green product assessment systems or methods The research on ecological (green) design products involves the current situation and trend of ecological design of green products ${ }^{[1]}$, domestic and foreign mechanisms of ecological assessment of products ${ }^{[2]}$, research progress of ecological design of industrial products ${ }^{[3]}$, research on green product design and its key technologies [4], standard institutionalized tools of ecological design of products ${ }^{[5]}$, etc. The research on the implementation of green product certification involves the technical methods for evaluating the implementation effect of green product certification ${ }^{[6]}$, the assessment of the implementation effect of green product certification in specific industries ${ }^{[7]}$, etc. The research on foreign green product assessment systems or methods involves EU eco-label system ${ }^{[8]}$, EU product environmental footprint assessment methods ${ }^{[9]}$, etc.

In addition, before China issued the Opinions on Establishing a Unified System of Standards,

* Corresponding author's e-mail address: zhuy@cnis.ac.cn 
Certification and Labelling of Green Products in 2016, various government departments had, according to the business development in respective fields, set up a number of "green product-related" standard systems and "green-related signs" from various angles such as environmental protection, energy conservation, water conservation, recycling, low carbon, regeneration and organic production. Up to now, the construction of China's unified green product standard system has just begun and is not yet mature. Therefore, based on the current theoretical research and system construction research on green product standardization at home and abroad, it is necessary to deeply explore and study China's unified management mechanism of green product standardization.

\section{Comparative Study on Green Product Assessment Standards between China and Foreign Countries}

Under the background of encouraging the production and consumption of green products at home and abroad, countries around the world are actively carrying out the standardization of green products. The international community, especially the European Union, Germany,
Canada, the United States and other countries, has achieved certain results in the standardization of green products. At present, about 40 countries and regions are implementing green product standardization systems, such as the Nordic Swan Ecolabel and standard system, the Blue Angel label and standard system in Germany, the ecological logo and standard system in Japan, the Green Seal and standard system in the United States, the Maple Leaf label and standard system in Canada, the Eco-label of Flower of Europe and standard system in Europe, etc. In 2016, China issued the Opinions on Establishing a Unified System of Standards, Certification and Labelling of Green Products, marking the beginning of China's construction of a unified green product standardization system. The following year, the Standardization Administration issued the General Principles for Green Product Assessment (GB/T 337612017), which clarified the concept of green products in China, unified the assessment methods and index system of green products, and provided a basis for the development of assessment standards for all kinds of green products. The comparative analysis of assessment standards for green products at home and abroad is shown in Table 1 below.

Table 1 The comparative analysis of assessment standards for green products at home and abroad

\begin{tabular}{|c|c|c|c|c|c|}
\hline $\begin{array}{c}\text { Name of } \\
\text { Label/Standard }\end{array}$ & Standard Range & $\begin{array}{l}\text { Standard } \\
\text { Quantity }\end{array}$ & $\begin{array}{l}\text { Standard Development and } \\
\text { Issuance Authority, and } \\
\text { Certification Authority }\end{array}$ & $\begin{array}{c}\text { Standard } \\
\text { Revision Cycle }\end{array}$ & $\begin{array}{c}\text { Standard Framework } \\
\text { Composition }\end{array}$ \\
\hline $\begin{array}{l}\text { EU Eco-Label } \\
\text { ("Flower of } \\
\text { Europe") }\end{array}$ & $\begin{array}{l}\text { Daily consumption } \\
\text { products, but excluding } \\
\text { food, beverages, drugs } \\
\text { and medical devices }\end{array}$ & 32 & $\begin{array}{l}\text { European Union Eco- } \\
\text { labelling Board (EUEB) }\end{array}$ & $\begin{array}{l}\text { About three to } \\
\text { five years }\end{array}$ & $\begin{array}{l}\text { 1. Harmful } \\
\text { substances banned } \\
\text { and limited } \\
\text { 2. Energy-saving } \\
\text { requirements } \\
\text { 3. Requirements of } \\
\text { user instruction } \\
\text { manual } \\
\text { 4. Eco-design for } \\
\text { recycling } \\
\text { 5. Prevent overuse } \\
\text { of detergent } \\
\text { 6. Property } \\
\text { 7. Reduce solid } \\
\text { waste } \\
\text { 8. Durability }\end{array}$ \\
\hline $\begin{array}{l}\text { German Blue } \\
\text { Angel }\end{array}$ & $\begin{array}{l}\text { Electrical appliances, } \\
\text { electronic products, } \\
\text { electronic equipment, } \\
\text { textiles and other products }\end{array}$ & 172 & $\begin{array}{l}\text { Environmental Label Jury, } \\
\text { German Institute for } \\
\text { Quality Assurance and } \\
\text { Certification (RAL), } \\
\text { Federal Ministry for the } \\
\text { Environment, Nature } \\
\text { Conservation, Building } \\
\text { and Nuclear Safety }\end{array}$ & $\begin{array}{l}\text { About every } \\
\text { three to five } \\
\text { years, standard } \\
\text { documents are } \\
\text { reviewed, } \\
\text { German eco- } \\
\text { labelled products } \\
\text { are updated, and } \\
\text { standards are } \\
\text { revised }\end{array}$ & $\begin{array}{l}\text { 1. Preliminary } \\
\text { remarks } \\
\text { 2. Scope } \\
\text { 3. Requirements } \\
\text { 4. Compliance } \\
\text { certification } \\
\text { 5. Use of the } \\
\text { Environmental label }\end{array}$ \\
\hline $\begin{array}{l}\text { Nordic Swan } \\
\text { Ecolabel }\end{array}$ & $\begin{array}{l}\text { Construction products, } \\
\text { cleaning products, } \\
\text { cosmetics/personal care, } \\
\text { electronics, food, forest } \\
\text { products/paper, } \\
\text { household appliances, } \\
\text { retail goods, textiles, } \\
\text { tourism } \\
\end{array}$ & 60 & $\begin{array}{l}\text { National administrations } \\
\text { organized by the Nordic } \\
\text { Council of Ministers }\end{array}$ & $\begin{array}{l}\text { About every } \\
\text { three to five } \\
\text { years, standard } \\
\text { documents are } \\
\text { reviewed, Nordic } \\
\text { eco-labelled } \\
\text { products are } \\
\text { updated, and }\end{array}$ & $\begin{array}{l}\text { 1. Environmental } \\
\text { requirements } \\
\text { 2. Efficiency } \\
\text { 3. Packaging } \\
\text { 4. Quality } \\
\text { regulations and } \\
\text { requirements }\end{array}$ \\
\hline
\end{tabular}




\begin{tabular}{|c|c|c|c|c|c|}
\hline & and other product groups & & & $\begin{array}{l}\text { standards are } \\
\text { revised }\end{array}$ & \\
\hline $\begin{array}{l}\text { Japanese Eco- } \\
\text { label }\end{array}$ & $\begin{array}{l}\text { Solar hot water supply } \\
\text { system, bags and } \\
\text { suitcases, printing ink, } \\
\text { clothing and other product } \\
\text { groups }\end{array}$ & 126 & $\begin{array}{l}\text { Japan Environmental } \\
\text { Association (JEA) }\end{array}$ & $\begin{array}{l}\text { About every } \\
\text { three to five } \\
\text { years, standard } \\
\text { documents are } \\
\text { reviewed, } \\
\text { Japanese eco- } \\
\text { labelled products } \\
\text { are updated, and } \\
\text { standards are } \\
\text { revised }\end{array}$ & $\begin{array}{l}\text { 1. Purpose of } \\
\text { Establishing } \\
\text { Certification Criteria } \\
\text { 2. Applicable Scope } \\
\text { 3. Terminology } \\
\text { 4. Certification } \\
\text { Criteria and } \\
\text { Certification } \\
\text { Procedure } \\
\text { 5. Product } \\
\text { Classification, } \\
\text { Indication and } \\
\text { Others }\end{array}$ \\
\hline $\begin{array}{l}\text { Australia's Good } \\
\text { Environmental } \\
\text { Choice Label }\end{array}$ & $\begin{array}{l}\text { Administrative services, } \\
\text { cleaning services and } \\
\text { other services, and } \\
\text { products such as } \\
\text { adhesives, architectural } \\
\text { and protective coatings, } \\
\text { broad polymers and } \\
\text { polymer-rich carpets }\end{array}$ & 26 & $\begin{array}{l}\text { Australian Environmental } \\
\text { Labelling Association }\end{array}$ & $\begin{array}{l}\text { About every } \\
\text { three to five } \\
\text { years, standard } \\
\text { documents are } \\
\text { reviewed, } \\
\text { Australian eco- } \\
\text { labelled products } \\
\text { are updated, and } \\
\text { standards are } \\
\text { revised }\end{array}$ & $\begin{array}{l}\text { 1. Introduction } \\
\text { 2. Standard category } \\
\text { scope } \\
\text { 3. Environmental } \\
\text { performance criteria } \\
\text { 4. Compliance to } \\
\text { environmental } \\
\text { regulations } \\
\text { 5. Compliance to } \\
\text { labor, anti- } \\
\text { discrimination and } \\
\text { safety regulations } \\
\text { 6. Compliance } \\
\text { testing }\end{array}$ \\
\hline $\begin{array}{l}\text { New Zealand's } \\
\text { Environmental } \\
\text { Choice Label }\end{array}$ & $\begin{array}{l}\text { Detergents, computers, } \\
\text { furniture, cosmetics, } \\
\text { textiles, recycled rubber, } \\
\text { packaging and cardboard } \\
\text { products, paints and other } \\
\text { products }\end{array}$ & 37 & $\begin{array}{l}\text { New Zealand Ecolabelling } \\
\text { Trust }\end{array}$ & $\begin{array}{l}\text { About every } \\
\text { three to five } \\
\text { years, standard } \\
\text { documents are } \\
\text { reviewed, New } \\
\text { Zealand eco- } \\
\text { labelled products } \\
\text { are updated, and } \\
\text { standards are } \\
\text { revised }\end{array}$ & $\begin{array}{l}\text { 1. Background } \\
\text { 2. Interpretation } \\
\text { 3. Category } \\
\text { definition } \\
\text { 4. Environmental } \\
\text { criteria } \\
\text { 5. Product } \\
\text { characteristics } \\
\text { 6. Requirements and } \\
\text { notes for license } \\
\text { holders }\end{array}$ \\
\hline $\begin{array}{l}\text { American Green } \\
\text { Seal }\end{array}$ & $\begin{array}{c}\text { Cleaning, fleet } \\
\text { maintenance and other } \\
\text { services, alternative fuel } \\
\text { vehicles, paint printing } \\
\text { paper and other products }\end{array}$ & 29 & $\begin{array}{l}\text { Environmental labelling } \\
\text { organization of the United } \\
\text { States }\end{array}$ & $\begin{array}{l}\text { About every } \\
\text { three to five } \\
\text { years, standard } \\
\text { documents are } \\
\text { reviewed, } \\
\text { American eco- } \\
\text { labelled products } \\
\text { are updated, and } \\
\text { standards are } \\
\text { revised }\end{array}$ & $\begin{array}{l}\text { 1. Product-specific } \\
\text { performance } \\
\text { requirements } \\
\text { 2. Packaging } \\
\text { requirements } \\
\text { 3. Labelling } \\
\text { requirements } \\
\text { 4. Product } \\
\text { information } \\
\text { labelling } \\
\text { requirements }\end{array}$ \\
\hline $\begin{array}{l}\text { Canadian Eco- } \\
\text { Logo }\end{array}$ & $\begin{array}{l}\text { Bamboo flooring and } \\
\text { other non-native wood } \\
\text { flooring, fiberboard made } \\
\text { of recycled materials, } \\
\text { sewer pipes, roof tiles, } \\
\text { thermal insulation } \\
\text { materials and other } \\
\text { products }\end{array}$ & 170 & $\begin{array}{l}\text { Terra Choice } \\
\text { Environmental Services } \\
\text { Inc. }\end{array}$ & $\begin{array}{l}\text { About every } \\
\text { three to five } \\
\text { years, standard } \\
\text { documents are } \\
\text { reviewed, } \\
\text { Canadian eco- } \\
\text { labelled products } \\
\text { are updated, and } \\
\text { standards are } \\
\text { revised }\end{array}$ & $\begin{array}{l}\text { 1. Introduction } \\
\text { 2. Notice } \\
\text { 3. Interpretation } \\
\text { 4. General } \\
\text { requirements } \\
\text { 5. Product specific } \\
\text { requirements } \\
\text { 6. Verification } \\
\text { 7. Conditions for } \\
\text { eco-logo use) }\end{array}$ \\
\hline
\end{tabular}




\begin{tabular}{|c|c|c|c|c|c|}
\hline $\begin{array}{l}\text { Singapore } \\
\text { Green Label }\end{array}$ & $\begin{array}{l}\text { Food packaging, pottery, } \\
\text { tableware and other } \\
\text { products }\end{array}$ & 52 & $\begin{array}{l}\text { Singapore Environment } \\
\text { Council }\end{array}$ & $\begin{array}{l}\text { About every } \\
\text { three to five } \\
\text { years, standard } \\
\text { documents are } \\
\text { reviewed, } \\
\text { Singapore eco- } \\
\text { labelled products } \\
\text { are updated, and } \\
\text { standards are } \\
\text { revised }\end{array}$ & $\begin{array}{l}\text { 1. Definitions } \\
\text { 2. Criteria } \\
\text { requirements } \\
\text { 3. Testing } \\
\text { requirements }\end{array}$ \\
\hline $\begin{array}{l}\text { Chinese green } \\
\text { product logo }\end{array}$ & $\begin{array}{l}\text { Consumer goods such as } \\
\text { plastic products, sanitary } \\
\text { ceramics, paper and paper } \\
\text { products }\end{array}$ & 15 & $\begin{array}{l}\text { The National Green } \\
\text { Product Assessment } \\
\text { Standardization Group } \\
\text { organizes the development } \\
\text { of standards, the } \\
\text { Standardization } \\
\text { Administration issues } \\
\text { standards, and the } \\
\text { Certification and } \\
\text { Accreditation } \\
\text { Administration organizes } \\
\text { the certification work }\end{array}$ & $\begin{array}{l}\text { Not more than } \\
\text { five years } \\
\text { standards are } \\
\text { revised }\end{array}$ & $\begin{array}{l}\text { 1. Foreword } \\
\text { 2. Scope } \\
\text { 3. Normative } \\
\text { references } \\
\text { 4. Terms and } \\
\text { definitions } \\
\text { 5. Evaluation } \\
\text { requirements } \\
\text { Including four } \\
\text { aspects: basic } \\
\text { requirements, } \\
\text { product resource } \\
\text { attributes, energy } \\
\text { attributes, } \\
\text { environmental } \\
\text { attributes and } \\
\text { quality attributes. }\end{array}$ \\
\hline
\end{tabular}

Through the comparative study of Chinese and foreign green product assessment standards, we can draw the following conclusions: (1) In terms of the scope of the standards involved, most of the Chinese and foreign green product assessment standards involve mainly consumer goods, while a few involve services, such as Australian Good Environmental Choice and American Green Seal standards. (2) In terms of organization and management, the development of foreign green product assessment standards and certification of foreign green products are managed by the same management and decision-making body, while the development of Chinese green product assessment standards and certification of green products are respectively managed by relatively independent decision-making departments of the Standardization Administration and the Certification and Accreditation Administration under the State Administration for Market Regulation. (3) In terms of the emphasis of standard index setting, most of the indicators involved in foreign standards focus on environmental protection, energy conservation and other aspects. For example, Germany's Blue Angel eco-label, Nordic Swan Ecolabel, Japan's eco-label, American Green Seal, Canadian Eco-Logo, Singapore Green Label, etc. are mainly designed with assessment indexes for environmental protection. On the other hand, the Chinese green product assessment standards involve more comprehensive indexes, covering four relatively comprehensive index ranges of resource attribute, energy attribute, environment attribute and quality attribute. (4) In terms of the assessment stages involved in those standards, some foreign standards (such as EU eco-label, Nordic Swan Ecolabel, Japanese eco-label, etc.) design indexes from the whole life cycle of products, and others (Germany Blue Angel, Australian Good Environmental Choice, Singapore Green Label, etc.) focus on some specific stages such as product use. Chinese standards require that when formulating specific green product assessment standards, we should start from the whole life cycle stages of raw material acquisition, manufacturing, use and abandonment, and focus on analyzing the resource and energy consumption, ecological environment impact and human health and safety impact factors of products in different stages.

\section{The Coordinated Management Mechanism of the Development of Green Product Assessment Standards and Certification of Green Products}

The development of green product assessment standards and certification of green products are respectively promoted and managed by the Standardization Administration (SAC) and the Certification and Accreditation Administration (CNCA) under the State Administration for Market Regulation (SAMR), and relevant work is coordinated and carried out by the two authorities. The management mechanism is shown in Figure 1.

In 2016, SAC approved the establishment of the National Green Product Assessment Standardization Group (hereinafter referred to as (GPSG). GPSG is responsible for coordinating and promoting the standardization of green product assessment, including formulating China's green product standardization development strategy and promotion measures, building the framework of China's green product assessment standard system, studying and putting forward the work plan of revising the national standard system for green product assessment, coordinating the technical contents and technical management of the national standards for 
green product assessment, organizing the technical management units to promote the revision plan of the national standards for green product assessment system, studying and proposing suggestions on the list of green product assessment standards, promoting the international standardization of green products, and promoting the application and implementation of green product standards.

The members of GPSG are composed of representatives of relevant trade associations, consumer organizations, standardization organizations, technical organizations, certification and testing organizations and experts, and GPSG adopts a dynamic adjustment mechanism according to the needs of the work. GPSG has a group leader, a deputy group leader, a secretary general, and a secretariat. The group leader is responsible for coordinating the overall work of the Group, and the deputy group leader assists the group leader in his/her work, including coordinating major issues of green product standardization, supervising the implementation of major issues, signing relevant important documents on behalf of GPSG, guiding and supervising the secretariat of GPSG to perform its duties, etc. The secretary general is responsible for the overall work of the secretariat. The secretariat is responsible for the day-to-day work of GPSG, including the preparing annual work plans and summaries of the work of GPSG and the secretariat, preparing and improving the green product standardization development strategy, promotion measures and the framework of the green product assessment standard system, organizing the technical management units to formulate project proposals of the national standards on green product assessment, promoting the development plan of the national standard system of green product assessment, formulating and implementing the publicity and implementation plans for green product assessment standards, etc. According to the needs of the work, GPSG will hold plenary meetings and special meetings to consider important and special issues to promote the development of green product assessment standardization, and coordinate and solve important problems in the standardization of green product assessment.

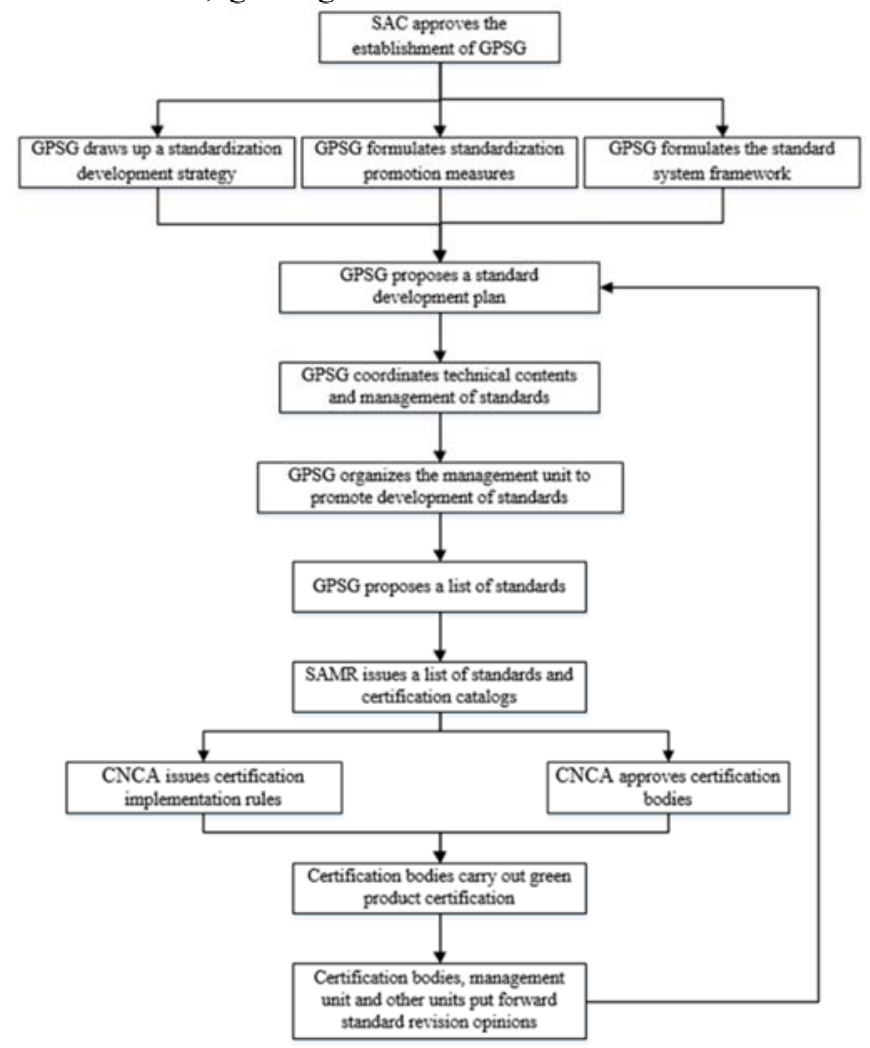

Figure1 The Coordinated Management Mechanism of the Development of Green Product Assessment Standards and Certification of Green Products

\section{Progress and Problem Analysis of Green Product Assessment Standardization in China}

The overall idea of the top-level design for the development of China's national standards for green product assessment is to focus on the product fields and categories with great ecological environment impact, strong consumer demand, strong industrial relevance, high social concern and large international trade volume. Priority is given to the means of livelihood, end consumer goods, food and other necessities of life for consumers, and the urgent needs for the development of national green product assessment standards are studied and put forward. Since 2017, a total of 14 national standards for green product assessment have been issued and implemented, involving coatings, furniture, textile products, paper and paper products, wood-based panels and wood flooring, plastic products, wood-plastic 
products, solar water heating systems, building glass, wall materials, thermal insulation materials, ceramic tiles (boards), sanitary ceramics, waterproof and sealing materials, etc. The standards being formulated involve more than 10 kinds of products such as detergents, tires, footwear products, electric toys, kitchen and toilet hardware products, express packaging products, household appliances, etc. By analysis, it is concluded that the published and formulated national standards for green product assessment conform to the overall idea of the top-level design, and the published standards have basically covered the key areas of larger categories of consumer goods..

According to the national standards for green product assessment, relevant organizations and localities in China have carried out the first trial of green product certification. Huzhou City, Zhejiang Province was approved as a national green product certification pilot city in 2018. According to the assessment standards of green products, Huzhou has built the working system and coordination mechanism of green product certification, as well as the organization system of green product certification. Besides, it has built the Huzhou Green Product Certification Alliance, optimized the technical support system of green product certification, studied and formulated relevant policies and factor guarantees, built the promotion system of green product certification, and formed the scale effect of green product certification. Huzhou has carried out green product certification trail in seven advantageous industries, including wood industry, furniture, textile printing and dyeing, coatings, storage batteries, ceramic plates (bricks), and paper and paper products. A total of 41 enterprises have passed green product certification with 61 certificates.

In addition, SAMR, CNCA and other departments have successively issued policy documents such as the List and Certification Catalogue of Green Product Assessment standards (First Batch), the Administrative Measures for the Use of the Green Product Labels, and the Qualification Conditions of Green Product Certification Institutions and the Implementation Rules of Green Product Certification (First Batch), providing a policy basis for carrying out green product certification according to the national standards.

Since the implementation of China's green product assessment standardization system, the results are remarkable, but green product assessment involves many fields, and the mechanism of coordination and cooperation among various parties still needs to be improved. In addition, encouraging and supporting policies need to be formulated quickly, and a marketoriented operation mechanism needs to be constructed and perfected to ensure the more effective implementation of the green product assessment standardization system.

\section{Suggestions on Standardization of Green Products}

This paper makes a comparative study of Chinese and foreign green product assessment standards, studies the coordination and management mechanism of green product standard development and green product certification of China, analyzes the progress and problems of China's green product assessment standardization, and thus puts forward the following suggestions for China's green product standardization.

\subsection{Formulate supporting policies encouraging and guiding green products}

on

China should establish a green procurement system of the government, encourage relevant government departments to adopt the results of third-party assessment, give priority to the procurement of products in the Green Product Catalogue through government adoption and other means, and promote relevant government departments to give preferential policies and fund support to enterprises carrying out energy conservation and environmental protection. We should promote bidding agencies to actively adopt green product catalogs, drive green technology progress and quality improvement of green products in enterprises, and facilitate the formation of a virtuous circle of coordinated development of technological innovation, standard development and industrial upgrading.

\subsection{Establish supervision and management policies for green products}

China should establish an effective supervision and management mechanism involving administrative supervision departments such as market supervision departments, price departments and environmental protection departments. At the same time, we should create a social supervision mechanism to safeguard the public's rights to know, participate and supervise. Special supervision and inspection should be organized for products with higher risks and more problems, and the results should be published in a timely manner and included in the social credit system. We should establish a strict entry and exit mechanism and a credit system for approving certification bodies. For the green product compliance catalogues established by the selfdeclaration method launched by relevant government departments, a blacklist publishing system should be built. In addition, a social supervision system should be set up to organize social forces to supervise and inspect various catalogue products, and use consumer complaints and feedback to make a list of dishonest enterprises.

\subsection{Encourage a market-oriented operation mechanism}

China should establish and improve the market-oriented operation mechanism for supporting green consumption, 
and standardize the production, management and consumption of green products. In particular, special attention should be given to the three key links of green consumption: strictly identifying and controlling the source of materials, and standardizing production process and environmental protection requirements in production link; stepping up publicity efforts to guide green consumption in product sales; and increasing efforts to help the superior products and control the inferior products, increasing penalties for noncompliance, and ensuring the orderly market of green products in market supervision link.

\section{Acknowledgements}

This work is supported by the Foundation of President of China National Institute of Standardization (542019Y-6659).

\section{References}

1. Min Jin. Present Situation and Development Trend of Product Ecological Design [C]. Small Refrigerator Cryobiomedical Committee of Chinese Association of Refrigeration. Proceedings of the 9th National Symposium on Air Conditioners, Refrigerators (Freezers) and Compressors. Small Refrigerator Cryobiomedical Committee of Chinese Association of Refrigeration: Chinese Association of Refrigeration, 2008: 266-273

2. Jianfang Zong, Jianhua Chen. Comparative Analysis of Domestic and Foreign Mechanisms for Ecological Evaluation of Products [J]. China Standardization, 2017 (15): 54-58+62.Another reference

3. Dongfeng Gao, Ling Lin, Yun Fu, Liang Chen, Jianhua Chen, Wei Bao, Xiuteng Wang, Jin Huang. Research Progress on Ecological Design of Industrial Products [J]. Standard Science, 2014 (07): 9-12.

4. Xujing Yang, Chuanqian Li. Review of Research on Green Product Design and Its Key Technologies [J]. Journal of Machine Design, 2001 (03): 1-3+44.

5. Jin Huang. Standardization Tool of IEAPD in Product's Eco-Design: Probing into ISO/TR 14062 [J]. World Standardization \& Quality Management, 2008 (11): 34-38.

6. Ruike Meng, Xiaoqing Li, Feng Gao, Youyang Lu, Hongtao Wang, Xiaofei Tian. Research on Evaluation Technology of Implementation Effect of Green Product Certification [J]. Science and Technology \& Innovation, 2018 (19): 28-32+37.

7. Ying Wang, Xiaoqing Li, Feng Gao, Ruike Meng. Case Study on Evaluation of Implementation Effect of Green Daily Chemical Product Certification [J]. China Cleaning Industry, 2019 (08): 99-106.

8. Yue Zhang, Chenxi Chen. Policy Implications of EU Eco-label System for China [J]. Intertrade, 2017 (08): 45-48.
9. Yun Fu, Ling Lin, Dongfeng Gao, Liang Chen, Lili Wu, Shan Hou. Research on the Assessment Method and Mechanism of EU Product Environmental Footprint [J]. China Standardization, 2013 (09): 5962.

10. General Office of the State Council. Opinions on Establishing a Unified System of Standards, Certification and Labeling of Green Products [S].[Publisher unknown]. 2016-11-22.

11. Yun Fu, Ling Lin, Dongfeng Gao. General Principles for Green Product Assessment(GB/T 33761-2017)[J]. Standard Living, 2018 (06): 34-37.

12. Lei Luo, Xiao Lu. Exploration and Practice of Establishing A Green Product Certification Pilot City in Huzhou [J]. China Quality Certification, 2019 (03): 82-83. 